\title{
Nauplius
}

The Journal OF The

Brazilian Crustacean Society

e-ISSN 2358-2936

www.scielo.br/nau www.crustacea.org.br

\section{Use of osmoregulatory ability to predict invasiveness of the Indo-Pacific swimming crab Charybdis hellerii (A. Milne-Edwards, 1867) an invader in Southern Brazil}

Thiago Vinícius Trento Occhi' (1) orcid.org/0000-0001-9746-4941

Jean Ricardo Simões Vitule 2 (1) orcid.org/0000-0001-6543-7439

Cassiana Baptista Metri ${ }^{3}$ (1D orcid.org/0000-0001-6432-4280

Viviane Prodocimo' (1) orcid.org/0000-0003-3567-5385

1 Departamento de Fisiologia, Setor de Ciências Biológicas, Universidade Federal do Paraná, Centro Politécnico, Curitiba, Paraná, 81531-990, Brazil.

2 Departamento de Engenharia Ambiental, Setor de Tecnologia, Universidade Federal do Paraná, Centro Politécnico, Curitiba, Paraná, 81531-990, Brazil

3 Departamento de Ciências Biológicas, Universidade Estadual do Paraná, Campus Paranaguá, Paranaguá, Paraná, 83203-280, Brazil.

ZOOBANK: http://zoobank.org/urn:lsid:zoobank.org:pub:08C8A1A9-F0C2-40AD88BB-A0F8057CA924

\section{Abstract}

The Indo-Pacific swimming crab Charybdis hellerii (A. Milne-Edwards, 1867) is native to the Indo-Pacific Ocean, and occurs as an invasive species along the Eastern American coast, where it was probably introduced in ballast water. The present study evaluated the osmoregulation and salinity tolerance of $C$. hellerii in Paranaguá Bay, Paraná, Brazil, an estuary under the constant threat of introduction of non-native species. The crabs were abruptly submitted to salinities of 10, 20, 30 (control), and 40 PSU for 24h. Hemolymph osmolality showed either an increase or a decrease following the changes in water salinity, presenting a pattern of hyper-osmoconformation. Muscle water content was stable at salinities from 20 to 40 PSU, and increased after exposure to 10 PSU indicating cellular swelling. At 10 PSU a physiological limit was reached, indicated by the failure of the capacity to regulate tissue water content. Although adult $C$. hellerii tolerate a wide range of salinities for $24 \mathrm{~h}$, its osmoregulatory ability indicates a possible advantage for its establishment in estuarine waters with salinities $<20$ PSU. The salinity

CORRESPONDING AUTHOR Viviane Prodocimo vprodocimo@ufpr.br

SUBMITTED 06 May 2019 ACCEPTED 23 September 2019 PUBLISHED 07 November 2019

DOI $10.1590 / 2358-2936 e 2019014$

\section{(cc) BY}

All content of the journal, except where identified, is licensed under a Creative Commons attribution-type BY.

Nauplius, 27: e2019014 


\section{INTRODUCTION}

Biological invasions can be extremely dangerous for species and ecosystems, generating impacts on taxonomic, functional and genetic diversity, as well as on food webs and may drive alterations in the environment (e.g., Simberloff and Vitule, 2014). In marine and estuarine habitats, biological invasions are a critical problem considering the constant propagule pressure from ship traffic and ballast water (e.g., Seebens et al., 2016). A high tolerance to environmental abiotic factors (e.g., salinity, temperature, dissolved oxygen, $\mathrm{pH}$ ) is a frequent characteristic of invasive species (e.g. Osovitz and Hofmann, 2007; Rahel and Olden, 2008; Blackburn et al., 2011; Gutierre et al., 2014; 2016; 2017; Rocha et al., 2017). With respect to estuaries, salinity is one of the main abiotic factors, and variations in salinity may limit the spread of many native and nonnative animals (e.g., Fowler et al., 2011; Gutierre et al., 2014, 2016, 2017; Rocha et al., 2017).

In order to maintain osmotic homeostasis, marine crustaceans usually keep the extracellular osmoticionic concentration close to external environment concentrations, and are classified as osmoconformers (e.g., Péqueux, 1995; Charmantier et al., 2009). When hemolymph osmolality changes, all cells will be osmotically challenged and will be induced to regulate their volume by intracellular isosmotic regulation (IIR), thus maintaining cell volume homeostasis (e.g., Péqueux, 1995; Freire et al., 2008a; 2008b; Charmantier et al., 2009). Moreover, when animals are exposed to the limit of their salinity tolerances, changes in the concentration of the extracellular medium can impose a large osmotic stress on the cells, and its ability to activate IIR may fail because it has reached the physiological limit (Freire et al., 2008b; Gutierre et al., 2017). Osmoregulatory ability allied to salinity tolerance could then be proposed as a useful indicator of the invasive potential of animals exposed to variations in salinities in estuaries (e.g., Gutierre et al., 2014; 2016; 2017; Rocha et al., 2017).

The invasive swimming crab Charybdis hellerii (A. Milne-Edwards, 1867) (Brachyura: Portunidae) is native to the Indo-Pacific Ocean and is now distributed in waters around the world (Tavares, 2011; Negri et al., 2018). Its introduction along the Eastern American coast (Caribbean, South Carolina and Florida (USA) and Brazil) was probably through ballast water (Campos and Türkay, 1989; Lemaitre, 1995; Mantelatto and Garcia, 2001; Negri et al., 2018). The first records in Brazil were in the Northeastern regions, later spreading through multiple introductions over almost the entire Brazilian coast (Mantelatto and Dias, 1999; Mantelatto and Garcia, 2001; Musiello-Fernandes et al., 2011; Negri et al., 2018). Charybdis hellerii was recorded in Guaratuba and Paranaguá Bay, Southern Brazil, by 2007 (Frigotto and Serafim-Junior, 2007).

Characteristics of $C$. hellerii, such as its fast growth and maturation, generalist carnivorous diet, multiple spawning, and two reproduction events per year (spring and winter), favor its ability to invade new environments. These characteristics, consequently, could generate negative impacts on native crustacean fauna through predation and/or competition (Dineen et al., 2001; Mantelatto and Dias, 1999; Mantelatto and Garcia, 2001; Bolaños et al., 2012; Sant'Anna et al., 2012). Little is known about the distribution of the Indo-Pacific swimming crab along salinity gradients in estuaries and there is no information on its osmoregulatory ability. Larvae of $C$. hellerii have been cultivated in the laboratory at 32 PSU (Dineen et al., 2001). In the estuary-bay complexes on the Southeastern Brazilian coastline this species was reported at salinities between 26-32 PSU (Sant'Anna et al., 2012). The osmoregulatory responses of $C$. hellerii to abrupt exposure to changes in salinity may help us understand its ability to survive and disperse through saline pathways during tidal cycle salinity fluctuations. In the present study, we evaluated the salinity tolerance and osmoregulatory responses of C. hellerii facing salt stress during short time exposures ( 24 hours). This study aims to explain how the crabs maintain their osmotic homeostasis when faced with daily salinity fluctuations in estuaries, highlighting the relationship of this ability to the crab's invasiveness. We hypothesize that a wide tolerance to fluctuations in salinity associated with osmoregulatory ability, could make adults of $C$. hellerii more prone to occupy and use new estuaries, which have high salinity variation (as observed for non-native species) (Osovitz and Hofmann, 2007; Fowler et al., 2011; Schofield et al., 2011; Gutierre et al., 2014; 2016; 2017; Rocha et al., 2017). 


\section{Material And Methods}

Adults of the Indo-Pacific swimming crab were obtained from Banana Island $\left(25^{\circ} 40^{\prime} \mathrm{S}, 48^{\circ} 23^{\prime} \mathrm{W}\right)$ and Governador Island $\left(25^{\circ} 48^{\prime} \mathrm{S}, 48^{\circ} 43^{\prime} \mathrm{W}\right)$, in Paranaguá Bay (range of salinity 24-29 PSU), State of Paraná, Brazil, from March 2014 to October 2015. Crabs were obtained using a local trap installed close to the rocks (depth $\sim 5$ meters), and baited with dead fish, mostly sardines. The traps remained in place for $16 \mathrm{~h}$, covering the tidal cycle. When the traps were retrieved, the animals were transferred to plastic gallon buckets with aerated water from the collection site. Water salinity was checked (refractometer Shibuya S-28, Japan) immediately after collecting the animals, and varied between 26 PSU and 28 PSU on the collection dates. Crabs were then transported to the laboratory and placed in 250L-tanks where they were acclimated for 5-7 days at a salinity of $30 \mathrm{PSU}$, temperature $\sim 20^{\circ} \mathrm{C}$, constant aeration, biological filtration, and natural photoperiod ( $\sim 13 \mathrm{~h}$ light: $11 \mathrm{~h}$ dark). Animals were daily fed ad libitum with fish filets during their acclimation.

After acclimation, animals ( $\mathrm{n}=8-10$ for each salinity) were directly transferred from seawater (30 PSU) to salinities of 10 PSU, 20 PSU, 30 PSU (control), and 40 PSU, always with one crab per vial (2-liter plastic box), and kept for 24 hours. Experiments were performed under constant aeration and at a temperature of $\sim 20^{\circ} \mathrm{C}$; animals were not fed during the experiment.

Animals exposed for 24 hours were than cryoanesthetized through immersion in crushed ice for 5 minutes. Hemolymph was obtained using a syringe $(10 \mathrm{~mL})$ puncture through the arthrodial membrane of one of the pereiopods. The sample was immediately frozen at $-20^{\circ} \mathrm{C}$ until assayed for osmolality using a vapor pressure osmometer (VAPRO 5520, Wescor, Logan, UT). A muscle slice ( $0.5 \mathrm{~g}$ ) was obtained from the penniform muscle of the cheliped, immediately weighed (precision $0.0001 \mathrm{~g}$ ) and dried $\left(60^{\circ} \mathrm{C}\right.$ for $24 \mathrm{~h}$ ) for the determination of its water content (\%) according to Freire et al. (2008b).

Results are presented as mean \pm standard deviation. Hemolymph osmolalities were evaluated using a Kruskal-Wallis test. One-way ANOVA was performed to evaluate the muscle water content. Bonferroni post hoc tests were used to discriminate differences within the experimental groups and control group (salinity $30 \mathrm{PSU}$ ) for both parameters (hemolymph osmolality and muscle water content). Tests of normality and equality of variances were also performed before each ANOVA or Kruskal-Wallis. All tests used a significance level $\alpha=0.05$. Statistical analyzes were performed using $\mathrm{R}$ software 1.3.3 software. Confidence intervals (CI, 95\%) were calculated for each data point of osmolality in the hemolymph to detect hyper- or hypo-regulation. Hyper or hypo-regulation was inferred when the CI did not include the respective water value estimated for that salinity.

\section{Results}

No mortality was observed in Charybdis hellerii after 24 hours of exposure to all experimental salinities. Over the experimental time period the animals became lethargic and stayed at the bottom of the aquarium in all salinities tested, including the control in 30 PSU. Hemolymph osmolality of the crabs decreased with lowered salinity (from 30 to 10 PSU) and increased at salinity $40 \mathrm{PSU}$. Crabs exposed to $10 \mathrm{PSU}\left(386 \pm 28.02 \mathrm{mOsm} / \mathrm{kg} \mathrm{H}_{2} \mathrm{O}\right)$ for 24 hours presented a lower hemolymph osmolality than crabs at $20 \mathrm{PSU}\left(678 \pm 15.7 \mathrm{mOsm} / \mathrm{kg} \mathrm{H}_{2} \mathrm{O}\right), 40 \mathrm{PSU}$ $\left(1077 \pm 42.04 \mathrm{mOsm} / \mathrm{kg} \mathrm{H}_{2} \mathrm{O}\right)$, and the control at 30 PSU ( $\left.815 \pm 72.5 \mathrm{mOsm} / \mathrm{kg} \mathrm{H}_{2} \mathrm{O}\right)$. Animals exposed to $40 \mathrm{PSU}$ showed an increase in hemolymph osmolality when compared to the control (30 PSU) (Fig. 1A). Applying 95\% confidence intervals to the mean and standard errors of osmolality, the ranges of hemolymph osmolality were CI: 409-364 mOsm $/ \mathrm{kg} \mathrm{H}_{2} \mathrm{O}$ for 10 PSU (water osmolality $2300 \mathrm{mOsm} / \mathrm{kg} \mathrm{H}_{2} \mathrm{O}$ ); CI: $690-667 \mathrm{mOsm} / \mathrm{kg} \mathrm{H}_{2} \mathrm{O}$ for $20 \mathrm{PSU}$ (water osmolality $\sim 600 \mathrm{mOsm} / \mathrm{kg} \mathrm{H}_{2} \mathrm{O}$ ); $\mathrm{CI}: 863-768 \mathrm{mOsm} / \mathrm{kg} \mathrm{H}_{2} \mathrm{O}$ for $30 \mathrm{PSU}$ (water osmolality $\sim 900 \mathrm{mOsm} / \mathrm{kg} \mathrm{H}_{2} \mathrm{O}$ ); CI: $1102-1053 \mathrm{mOsm} / \mathrm{kg} \mathrm{H}_{2} \mathrm{O}$ for $40 \mathrm{PSU}$ (water osmolality $\sim 1200 \mathrm{mOsm} / \mathrm{kg} \mathrm{H}_{2} \mathrm{O}$ ).

Muscle water content from animals exposed to 10 PSU $(82.8 \pm 1.94 \%)$ was elevated when compared to animals in $20 \mathrm{PSU}(78.4 \pm 1.51 \%), 30 \mathrm{PSU}$ (75.6 $\pm 2.04 \%)$, and $40 \mathrm{PSU}(75.8 \pm 2.74 \%)$. There was no difference between muscle water content in crabs exposed to 20 PSU, 30 PSU and 40 PSU (Fig. 1B). 

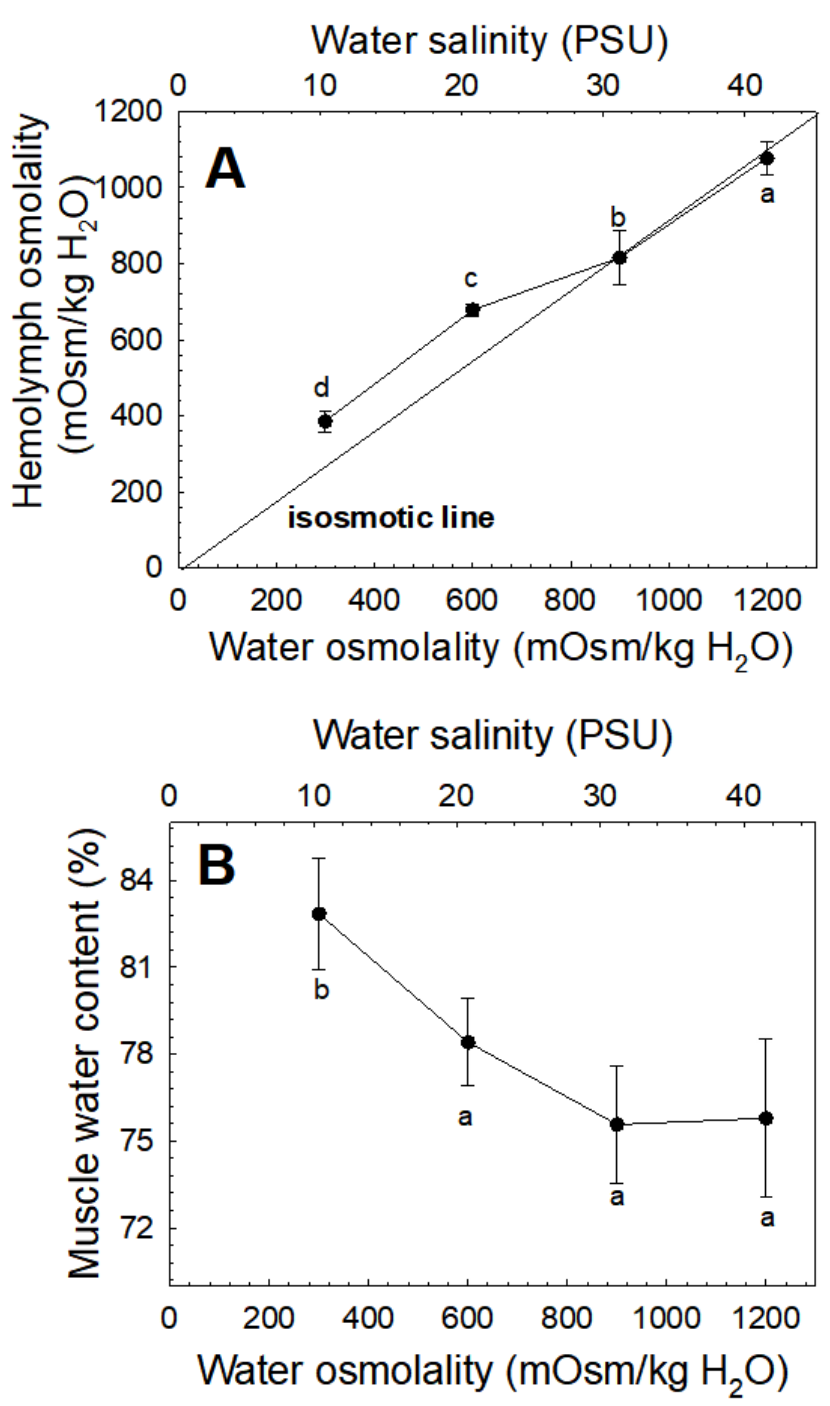

Figure 1. A, Hemolymph osmolality ( $\left.\mathrm{mOsm} / \mathrm{kg} \mathrm{H}_{2} \mathrm{O}\right)$, and $\mathrm{B}$, muscle water content (\%) (mean \pm S.D.) of Charybdis hellerii exposed to salinities 10 PSU, 20 PSU, 40 PSU, and 30 PSU (control) for 24 hours $(4<\mathrm{n}<11$ for both parameters). Symbols that share the same letter represent groups that are not significantly different.

\section{Discussion}

Charybdis hellerii demonstrated a wide salinity tolerance (from $10 \mathrm{PSU}$ to $40 \mathrm{PSU}$ ) in 24 hour experiments. Similar results have been observed in other Portunidae crabs [Scylla serrata (Forskal, 1775) and Portunus pelagicus (Linnaeus, 1759)] exposed to salinities ranging from $\sim 10$ to $45 \mathrm{PSU}$ for 24 hours (Chen and Chia, 1997; Romano and Zeng, 2006). Our findings indicate that adults of $C$. hellerii can tolerate the type of reductions in salinity commonly seen in coastal regions or estuaries for a short exposure time. This tolerance would guarantee its survival and help with the success of invasion in environments where the variation in salinity ( 0-32 PSU) occurs during tidal cycles of $\sim 6$ hours, as observed in estuaries of Southern Brazil.

Concomitant with salinity tolerance, the IndoPacific swimming crab showed hemolymph dilution at low salinities (20 PSU and 10 PSU) and hemolymph concentration at salinity 40 PSU. The confidence intervals for hemolymph osmolality did not include the range of confidence intervals of the water osmolality for these salinities. However, the maintenance of a higher water-hemolymph gradient was observed at salinities of 10 PSU and 20 PSU indicating hyperregulation. On the other hand, at salinities of $30 \mathrm{PSU}$ and $40 \mathrm{PSU}$, the water-hemolymph gradient was small, with the hemolymph practically isosmotic to the water, characterizing $C$. hellerii as a hyper-osmoconformer (e.g., Péqueux, 1995; Romano and Zeng, 2006; Freire et al., 2008a; 2008b; Foster et al., 2010; Charmantier et al., 2009). Values of hemolymph osmolality measured in the control (30 PSU) were similar to those previously determined for Portunidae crabs $(\sim 820 \mathrm{mOsm} / \mathrm{kg}$ $\mathrm{H}_{2} \mathrm{O}$ - e.g., Romano and Zeng, 2006; Freire et al., $2011)$. When subjected to a salinity of $10 \mathrm{PSU}(\sim 390$ $\mathrm{mOsm} / \mathrm{kg} \mathrm{H}_{2} \mathrm{O}$ ), the observed hemolymph dilution was much more pronounced than that seen in other Portunidae crabs (which naturally occur at more dilute salinities), such as Callinectes sapidus Rathbun, 1896, C. similis Williams, 1966 and Portunus pelagicus $\left(\sim 600-700 \mathrm{mOsm} / \mathrm{kg} \mathrm{H}_{2} \mathrm{O}\right)$ kept at the same salinity for 14-67 days (Piller et al., 1995; Guerin and Stickle, 1997; Romano and Zeng, 2006). However, for $C$. hellerii the reduction in osmolality was similar to that seen in Callinectes danae Smith, 1869 and C. ornatus Ordway, 1863 ( $\left.\sim 500-680 \mathrm{mOsm} / \mathrm{kg} \mathrm{H}_{2} \mathrm{O}\right)$ when exposed to 20 PSU for hours or days (Freire et al., 2011). It is important to highlight that despite this hemolymph dilution its internal medium remained significantly hyper-osmotic in salinities $10 \mathrm{PSU}$ and 20 PSU ( $\sim 300$ and $\left.600 \mathrm{mOsm} / \mathrm{kg} \mathrm{H}_{2} \mathrm{O}\right)$, and practically isosmotic in 30 and $40 \mathrm{PSU}$, showing hyper-isosmotic osmoregulation (e.g., Charmantier et al., 2009).

Accompanying the reduction in hemolymph osmolality at salinity of 10 PSU (compared to control), the Indo-Pacific swimming crab presented an increase in muscle water content, indicating a physiological disturbance of cell homeostasis. When the extracellular 
osmolality changes, the cells quickly activate IIR, modifying solute and water fluxes. Facing the dilution of osmolality, as observed in C. hellerii exposed to 10 PSU, mechanisms for regulating cell volume (solute and water efflux from the cell) could not maintain the water content in the muscle, which led to the cells swelling and to an increase in the percentage of water in the tissue (Freire et al., 2008b; Foster et al., 2010). On the other hand, despite an increase in hemolymph osmolality, from $815 \pm 24 \mathrm{mOsm} / \mathrm{kg} \mathrm{H}_{2} \mathrm{O}$ in $30 \mathrm{PSU}$ to $1077 \pm 13 \mathrm{mOsm} / \mathrm{kg} \mathrm{H}_{2} \mathrm{O}$ in $40 \mathrm{PSU}, \mathrm{C}$. hellerii muscle water content remained unchanged following the salinity increase. This result can indicate an activation of isosmotic intracellular regulation, probably by the increase of organic osmolytes in the cellular content (Hoffmann and Dunham, 1995; Gilles, 1997).

The observed salinity tolerance is an indicator of the invasive potential of adult $C$. hellerii in estuarine habitats. However, despite tolerating salinities between 10 PSU and 20 PSU for 24 hours, the species tolerance is limited by osmotic stress (as observed for muscle water content increase and osmolality decrease), which compromises the osmo-ionic homeostasis at 10 PSU. Further studies should be conducted to test salinity tolerance limits and the osmoregulatory capacity of this species over longer periods of exposure (Hoffmann and Dunham, 1995; Gilles, 1997; Freire et al., 2008a; 2008b; Foster et al., 2010; Freire et al., 2013).

In conclusion, Charybdis hellerii was able to tolerate salinity from 10 PSU to 40 PSU for 24 hours. The capacity to survive in a wide range of salinity conditions for 24 hours could support the species' invasiveness in the estuary-bay complexes on the Southeastern Brazilian coastline with a 6-hour tide cycle (e.g., Gutierre et al., 2014; Sant'Anna et al., 2012). However, after 24 hours of salinity exposure the dilution of the hemolymph led to increases in cell water content at salinity 10 PSU. These physiological variations indicate osmotic stress to cells, which may limit its survival in low salinities for prolonged periods. Salinity tolerance and osmoregulatory ability of adults of $C$. hellerii for short times (24 hours) may favor the use of estuaries for dispersal, especially through areas of salinity over 20 PSU, as observed in estuaries from Southern Brazil with heavy ship trafficking. The salinity tolerance and osmoregulatory ability data are a fundamental key for use in modeling studies aimed at predicting the potential distributions of invasive species (e.g., Gallien et al., 2010; Rocha et al., 2017), and may help in predicting and preventing invasions of $C$. hellerii in the Neotropics.

\section{ACKNOWLeDgementS}

JRSV is thankful for receiving a continuous Grant from $\mathrm{CNPq}$ for research productivity (PQ Process Number: 310850/2012-6; 303776/2015-3). TVTO is thankful for the scholarships received from CAPES. Authors also thank both anonymous reviewers and editors for their kind and helpful evaluation of the manuscript, comments and suggestions for improvement. Authors are also grateful to Dr. James Nienow for kindly revising the English in the latest version of manuscript.

\section{References}

Bolaños, J.A.; Baeza, J.A.; Hernandez, J.E.; Lira, C. and López, R. 2012. Population dynamics and reproductive output of the non-indigenous crab Charybdis hellerii in the south-eastern Caribbean Sea. Journal of the Marine Biological Association $U K$, 92: 469-474.

Blackburn, T.M.; Pyšek, P.; Bacher, S.; Carlton, J.T.; Duncan, R.P.; Jarošík, V.; Wilson, J.R.U. and Richardson, D.M. 2011.A proposed unified framework for biological invasions. Trends in Ecology \& Evolution, 26: 333-339.

Campos, N.H. and Türkay, M. 1989. On a record of Charybdis hellerii from the Caribbean coast of Colombia. Senckenbergiana maritima, 20: 119-123.

Charmantier, G.; Charmantier-Daures, M. and Towle, D. 2009. Osmotic and ionic regulation in aquatic arthropods. p. 165230. In: D.H. Evans (ed), Osmotic and ionic regulation: cells and animals. Boca Raton, CRC Press.

Chen, J-C. and Chia, P-G. 1997. Osmotic and ionic concentrations of Scylla serrata (Forskal) subjected to different salinity levels. Comparative and Biochemistry Physiology A, 117: 239-244.

Dineen, J.F.; Clark, P.F.; Hines, A.H.; Reed, S.A. and Walton, H.P. 2001. Life history, larval description, and natural history of Charybdis hellerii (Decapoda, Brachyura, Portunidae), an invasive crab in the Western Atlantic. Journal of Crustacean Biology, 21: 774-805.

Foster, C.; Amado, E.M.; Souza, M.M. and Freire, C.A. 2010. Do osmoregulators have lower capacity of muscle water regulation than osmoconformers? A study on decapod crustaceans. Journal of Experimental Zoology A, 313: 80-94.

Fowler, A.E.; Gerner, N.V. and Sewell, M.A. 2011. Temperature and salinity tolerances of Stage 1 zoeae predict possible range expansion of an introduced portunid crab, Charybdis japonica, in New Zealand. Biological Invasions, 13: 691-699.

Freire, C.A.; Onken, H. and McNamara, J.C. 2008a. A structurefunction analysis of ion transport in crustacean gills and excretory organs. Comparative Biochemistry and Physiology A, 151:272-304. 
Freire, C.A.; Amado, E.M.; Souza, L.R.; Veiga, M.P.; Vitule, J.R.S.; Souza, M.M. and Prodocimo, V. 2008b. Muscle water control in crustaceans and fishes as a function of habitat, osmoregulatory capacity, and degree of euryhalinity. Comparative Biochemistry and Physiology A, 149: 435-446.

Freire, C.A.; Togni, V.G. and Hermes-Lima, M. 2011. Responses of free radical metabolism to air exposure or salinity stress, in crabs (Callinectes danae and C. ornatus) with different estuarine distributions. Comparative Biochemistry and Physiology A, 160: 291-300.

Freire, C.A.; Souza-Bastos, L.R.; Amado, E.M.; Prodocimo, V. and Souza, M.M. 2013. Regulation of muscle hydration upon hypo- or hyper-osmotic shocks: Differences related to invasion of the freshwater habitat by decapod crustaceans. Journal of Experimental Zoology A, 319: 297-309.

Frigotto, S.F. and Serafim-Junior, M. 2007. Primeiro registro de Charybdis hellerii (Milne Edwards, 1867) (Crustacea) no litoral do estado do Paraná [First record of Charybdis hellerii (Milne Edwards, 1867) (Crustacea) in the coast of the state of Paraná]. Estudos de Biologia, 29: 227-230.

Gallien, L.; Münkemüller, T.; Albert, C.H.; Boulangeat, I. and Thuiller, W.2010. Predicting potential distributions of invasive species: where to go from here? Diversity and Distributions, 16: $331-342$.

Gilles, R. 1997. “Compensatory” organic osmolytes in high osmolarity and dehydration stresses: History and perspectives. Comparative Biochemistry and Physiology A, 117: 279-290.

Guerin, J.L. and Stickle, W.B. 1997. A comparative study of two sympatric species within the genus Callinectes: osmoregulation, long-term acclimation to salinity and the effects of salinity on growth and moulting. Journal of Experimental Marine Biology and Ecology, 218: 165-186.

Gutierre, S.M.M.; Schofield, P.J. and Prodocimo, V. 2016. Salinity and temperature tolerance of an emergent alien species, the Amazon fish Astronotus ocellatus. Hydrobiologia, 777: 21-31.

Gutierre, S.M.M.; Schulte, J.M.; Schofield, P.J. and Prodocimo, V. 2017. Osmoregulation and muscle water control in vitro facing salinity stress of the Amazon fish Oscar Astronotus ocellatus (Cichlidae). Marine and Freshwater Behaviour and Physiology, 50: 303-311.

Gutierre, S.M.M.; Vitule, J.R.S.; Freire. C.A. and Prodocimo, V. 2014. Physiological tools to predict invasiveness and spread via estuarine bridges: tolerance of Brazilian native and worldwide introduced freshwater fishes to increased salinity. Marine and Freshwater Research, 65: 425-436.

Hoffmann, E.K. and Dunham, P.B. 1995. Membrane mechanisms and intracellular signalling in cell volume regulation. International Review of Cytology, 161:173-262.

Lemaitre, R. 1995. Charybdis hellerii (Milne Edwards, 1867), a nonindigenous portunid crab (Crustacea: Decapoda: Brachyura) discovered in the Indian River lagoon system of Florida. Proceedings of the Biological Society of Washington, 108: 643-648.

Mantelatto, F.L. and Dias, L.L. 1999. Extension of the known distribution of Charybdis hellerii (A. Milne-Edwards, 1867) (Decapoda, Portunidae) along the western tropical South Atlantic. Crustaceana, 72: 617-620.
Mantelatto, F.L. and Garcia, R.B. 2001. Biological aspects of the nonindigenous portunid crab Charybdis hellerii in the western tropical south Atlantic. Bulletin of Marine Science, 68: 469-477.

Musiello-Fernandes, J.; Vilar, C.C. and Rosa, D.M. 2011. Ocorrência da espécie exótica Charybdis hellerii Milne Edwards, 1867 (Crustacea, Portunidae) no litoral do Espírito Santo [The occurrence of the exotic species Charybdis hellerii Milne Edwards, 1867 (Crustacea, Portunidae) at the coast of Espirito Santo State]. Natureza on line, 9: 35-37.

Negri, M.; Schubart, C.D. and Mantelatto, F.L. 2018. Tracing the introduction history of the invasive swimming crab Charybdis hellerii (A. Milne-Edwards, 1867) in the Western Atlantic: evidences of high genetic diversity and multiple introductions. Biological Invasions, 20: 1771-1798.

Osovitz, C.J. and Hofmann, G.E. 2007. Marine macrophysiology: Studying physiological variation across large spatial scales in marine systems. Comparative Biochemistry and Physiology A, 147: 821-827.

Péqueux, A. 1995. Osmotic regulation in crustaceans. Journal of Crustacean Biology, 15: 1-60.

Piller, S.C.; Henry, R.P.; Doeller, J.E. and Kraus, D.W. 1995. A comparison of the gill physiology of two euryhaline crab species, Callinectes sapidus and Callinectes similis: energy production, transport-related enzymes and osmoregulation as a function of acclimation salinity. Journal of Experimental Biology, 198: 349-358.

Rahel, F.J. and Olden, J.D. 2008. Assessing the effects of climate change on aquatic invasive species. Conservation Biology, 22: 521-533.

Rocha, R.M.; Castellano, G.C. and Freire, C.A. 2017. Physiological tolerance as a tool to support invasion risk assessment of tropical ascidians. Marine Ecology Progress Series, 577: 105119.

Romano, N. and Zeng, C. 2006. The effects of salinity on the survival, growth and haemolymph osmolality of early juvenile blue swimmer crabs, Portunus pelagicus. Aquaculture, 260: 151-162.

Sant’Anna, B.S.; Watanabe, T.T.; Turra, A. and Zara, F.J. 2012. Relative abundance and population biology of the nonindigenous crab Charybdis hellerii (Crustacea: Brachyura: Portunidae) in a southwestern Atlantic estuary-bay complex. Aquatic Invasions, 7: 347-356.

Schofield, P.J.; Peterson, M.S.; Lowe, M.R.; Brown-Peterson, N.J. and Slack, W.T. 2011. Survival, growth and reproduction of non-indigenous Nile tilapia, Oreochromis niloticus (Linnaeus 1758). I. Physiological capabilities in various temperatures and salinities. Marine and Freshwater Research, 62: 439-449.

Seebens, H.; Schwartz, N.; Schupp, P.J. and Blasius, B. 2016. Predicting the spread of marine species introduced by global shipping. Proceedings of the National Academy of Sciences of the United States of America, 13: 5646-5651.

Simberloff, D. and Vitule, J.R.S. 2014. A call for an end to calls for the end of invasion biology. Oikos, 123: 408-413.

Tavares, M. 2011. Alien Decapod crustaceans in the Southwestern Atlantic Ocean. p. 251-268. In: B. Galil; P. Clark and J. Carlton (eds), In the wrong place - alien marine crustaceans: distribution, biology and impacts. Invading Nature - Springer Series in Invasion Ecology. Vol 6. Dordrecht, Springer. 